\title{
Colwellia aestuarii sp. nov., isolated from a tidal flat sediment in Korea
}

\author{
Seo-Youn Jung, Tae-Kwang Oh and Jung-Hoon Yoon \\ Korea Research Institute of Bioscience and Biotechnology (KRIBB), PO Box 115, Yusong, \\ Taejon, South Korea
}

Correspondence

Jung-Hoon Yoon

jhyoon@kribb.re.kr
A novel Colwellia-like bacterial strain, $\mathrm{SMK}-10^{\top}$, was isolated from a tidal flat sediment in Korea and subjected to a polyphasic taxonomic analysis. Cells of strain SMK-10 $0^{\top}$ were Gram-negative, motile, greyish yellow-pigmented, curved rods. Optimal growth occurred at $25-30{ }^{\circ} \mathrm{C}$ and in the presence of $2-3 \%(\mathrm{w} / \mathrm{v}) \mathrm{NaCl}$. Strain $\mathrm{SMK}-10^{\top}$ contained $\mathrm{Q}-8$ as the predominant ubiquinone and $\mathrm{C}_{16: 1} \omega 7 \mathrm{c}$ and/or iso- $\mathrm{C}_{15: 0} 2-\mathrm{OH}, \mathrm{C}_{17: 1}, \mathrm{C}_{15: 1}$ and iso- $\mathrm{C}_{16: 0}$ as major fatty acids. The DNA G $+\mathrm{C}$ content was $39 \cdot 3$ mol\%. Phylogenetic trees based on 16S rRNA gene sequence analysis showed that strain SMK-10 $0^{\top}$ belonged to the genus Colwellia. 16S rRNA gene sequence similarity values $(94 \cdot 7-96 \cdot 7 \%)$ to the type strains of all other Colwellia species and various differential phenotypic properties were sufficient to distinguish strain SMK-10 ${ }^{\top}$ from recognized Colwellia species. On the basis of its phenotypic properties and phylogenetic distinctiveness, strain SMK $-10^{\top}\left(=\right.$ KCTC $12480^{\top}=$ DSM $\left.17314^{\top}\right)$ is classified as the type strain of a novel Colwellia species, for which the name Colwellia aestuarii sp. nov. is proposed.
The family Colwelliaceae, which belongs to the Gammaproteobacteria (Ivanova et al., 2004), includes the genera Colwellia and Thalassomonas. This family accommodates bacteria with cells that are Gram-negative, motile or nonmotile, chemo-organotrophic, curved rods or straight rods, psychrophilic and/or halophilic, and contain ubiquinone- 8 as the predominant isoprenoid quinone (Yumoto et al., 1998; Nogi et al., 2004; Yi et al., 2004; Ivanova et al., 2004). At the time of writing, the genus Colwellia comprises eight species, Colwellia psychrerythraea and C. hadaliensis (Deming et al., 1988), C. demingiae, C. hornerae, C. psychrotropica and C. rossensis (Bowman et al., 1998), C. maris (Yumoto et al., 1998) and C. piezophila (Nogi et al., 2004). The genus Thalassomonas comprises two species, Thalassomonas viridans (Macián et al., 2001) and T. ganghwensis (Yi et al., 2004). Recently, a bacterial strain, SMK $-10^{\mathrm{T}}$, cells of which were Gram-negative, greyish-yellow-pigmented, curved rods, was isolated from a tidal flat sediment in Korea. 16S rRNA gene sequence comparison indicated that strain SMK-10 ${ }^{\mathrm{T}}$ is phylogenetically related to the family Colwelliaceae. Accordingly, the aim of the present study was to determine the exact taxonomic position of strain SMK- $10^{\mathrm{T}}$ by using a combination of polyphasic taxonomic data.

Tidal flat sediment collected from Saemankum, Pyunsan, Korea, was used as the source for the isolation of bacterial

Published online ahead of print on 26 August 2005 as DOI 10.1099/ ijs.0.63920-0.

The GenBank/EMBL/DDBJ accession number for the 16S rRNA gene sequence of strain SMK-10 $10^{\top}$ is DQ055844. strains. Strain SMK- $10^{\mathrm{T}}$ was isolated by the dilution plating technique on marine agar 2216 (MA; Difco) at $30^{\circ} \mathrm{C}$. C. hornerae CIP $105821^{\mathrm{T}}$ and C. maris CIP $106458^{\mathrm{T}}$, which were obtained from the Collection de l'Institut Pasteur (CIP), Paris, France, were used as reference strains for fatty acid analysis. Cell morphology and presence of flagella were examined by light microscopy (Nikon E600) and transmission electron microscopy (TEM) by using cells grown on MA. The Gram reaction was determined by using the bioMérieux Gram Stain kit according to the manufacturer's instructions. Growth at various temperatures from 4 to $40{ }^{\circ} \mathrm{C}$ was measured on $\mathrm{MA}$, and tolerance to various $\mathrm{NaCl}$ concentrations was measured in marine broth 2216 (MB; Difco). The $\mathrm{pH}$ range for growth and optimal $\mathrm{pH}$ were determined in $\mathrm{MB}$ that was adjusted to various $\mathrm{pH}$ values (initial $\mathrm{pH} 4 \cdot 5-9 \cdot 0$ at intervals of $0.5 \mathrm{pH}$ units). Growth in the absence of $\mathrm{NaCl}$ was investigated in R2A agar (Difco) and trypticase soy broth prepared according to the formula for the Difco medium except that no $\mathrm{NaCl}$ was used. Growth under anaerobic conditions was determined after incubation in an anaerobic chamber on MA and on MA supplemented with nitrate, both of which had been prepared anaerobically using nitrogen. Catalase and oxidase activity and hydrolysis of casein and starch were determined as described by Cowan \& Steel (1965). Hydrolysis of hypoxanthine, tyrosine and xanthine was investigated on MA with the substrate concentrations described by Cowan \& Steel (1965). Hydrolysis of aesculin, gelatin and urea, and nitrate reduction were studied as described by Lanyi (1987) with the modification that artificial sea water (containing $23.6 \mathrm{~g}$ $\mathrm{NaCl}, 0 \cdot 64 \mathrm{~g} \mathrm{KCl}, 4 \cdot 53 \mathrm{~g} \mathrm{MgCl}_{2} \cdot 6 \mathrm{H}_{2} \mathrm{O}, 5 \cdot 94 \mathrm{~g} \mathrm{MgSO}_{4} .7 \mathrm{H}_{2} \mathrm{O}$ 
and $1.3 \mathrm{~g} \mathrm{CaCl}_{2} \cdot 2 \mathrm{H}_{2} \mathrm{O}$ per litre distilled water; Bruns et al., 2001) was used for the preparation of media. Hydrolysis of Tweens 20, 40, 60 and 80 was determined as described by Cowan \& Steel (1965) with the modification that artificial sea water was used for the preparation of media. Acid production from carbohydrates was determined as described by Leifson (1963). Utilization of various substrates as sole carbon and energy sources was tested according to the method of Baumann \& Baumann (1981), using supplementation with $2 \%(\mathrm{v} / \mathrm{v})$ Hutner's mineral base (CohenBazire et al., 1957), 1 \% (v/v) vitamin solution (Staley, 1968) and $0.005 \%(\mathrm{w} / \mathrm{v})$ yeast extract. The API ZYM system (bioMérieux) was used to determine enzyme activities. Antibiotic sensitivity was tested by spreading bacterial suspension on MA and applying discs impregnated with the following antibiotics (concentration per disc): ampicillin $(10 \mu \mathrm{g})$, carbenicillin $(100 \mu \mathrm{g})$, cephalothin $(30 \mu \mathrm{g})$, chloramphenicol $(100 \mu \mathrm{g})$, gentamicin $(30 \mu \mathrm{g})$, lincomycin $(15 \mu \mathrm{g})$, kanamycin $(30 \mu \mathrm{g})$, neomycin $(30 \mu \mathrm{g})$, novobiocin $(5 \mu \mathrm{g})$, oleandomycin $(15 \mu \mathrm{g})$, penicillin $\mathrm{G}(20 \mathrm{U})$, polymyxin B $(100 \mathrm{U})$, streptomycin $(50 \mu \mathrm{g})$ and tetracycline $(30 \mu \mathrm{g})$.

Strain SMK- $10^{\mathrm{T}}$ was cultivated for 3 days in $\mathrm{MB}$ at $30^{\circ} \mathrm{C}$ to obtain the cell mass required for isoprenoid quinone analysis and DNA extraction. Isoprenoid quinones were extracted according to the method of Komagata \& Suzuki (1987) and analysed using reversed-phase HPLC and a YMC ODS-A $(250 \times 4.6 \mathrm{~mm})$ column. For fatty acid methyl ester analysis, cell mass of strain SMK-10 ${ }^{\mathrm{T}}$ was harvested from agar plates after cultivation for 3 days at $30^{\circ} \mathrm{C}$ on MA; cell mass of $C$. maris CIP $106458^{\mathrm{T}}$ was obtained from 5 days cultivation at $15^{\circ} \mathrm{C}$ on PYSE agar (Yumoto et al., 1998) and cell mass of $C$. hornerae CIP $105821^{\mathrm{T}}$ was obtained from 7 days cultivation at $10^{\circ} \mathrm{C}$ on MA. The fatty acid methyl esters were extracted and prepared according to the standard protocol of the MIDI/Hewlett Packard Microbial Identification System (Sasser, 1990). Chromosomal DNA was extracted and purified by the procedure described by Yoon et al. (1996). The DNA G + C content was determined by the method of Tamaoka \& Komagata (1984) with a modification that DNA was hydrolysed and the resulting nucleotides were analysed by reversed-phase HPLC. Amplification of the 16S rRNA gene was performed according to the method described by Yoon et al. (1998) using two universal primers. Sequencing of the amplified 16S rRNA gene and phylogenetic analysis were performed as described by Yoon et al. (2003).

Morphological, cultural, physiological and biochemical characteristics of strain SMK-10 ${ }^{\mathrm{T}}$ are shown in Table 1 or are given in the species description below. The predominant ubiquinone detected in strain SMK-10 ${ }^{\mathrm{T}}$ was Q-8 at a peak area ratio of approximately $98 \%$. The cellular fatty acid profile of strain SMK $-10^{\mathrm{T}}$ is given in Table 2, together with those of some other Colwellia species. The profile of strain SMK- $10^{\mathrm{T}}$ was characterized by large amounts of unsaturated, straight-chain, branched and hydroxy fatty acids; the major components ( $>10 \%$ of the total) were $\mathrm{C}_{16: 1} \omega 7 c$ and/ or iso- $\mathrm{C}_{15: 0} 2-\mathrm{OH}, \mathrm{C}_{17: 1}, \mathrm{C}_{15: 1}$ and iso- $\mathrm{C}_{16: 0}$. The DNA $\mathrm{G}+\mathrm{C}$ content of strain SMK $-10^{\mathrm{T}}$ was $39 \cdot 3 \mathrm{~mol} \%$.

The 16S rRNA gene sequence of strain SMK- $10^{\mathrm{T}}$ determined in this study comprised $1496 \mathrm{nt}$, representing approximately $96 \%$ of the Escherichia coli $16 \mathrm{~S}$ rRNA gene sequence. In the phylogenetic tree based on the neighbour-joining algorithm, strain SMK- $10^{\mathrm{T}}$ joined the cluster comprising Colwellia species at a bootstrap resampling value of $93.4 \%$ (Fig. 1). Strain SMK- $10^{\mathrm{T}}$ exhibited $16 \mathrm{~S}$ rRNA gene sequence similarity values of $94 \cdot 7-96 \cdot 7 \%$ to the type strains of seven Colwellia species and of $94 \cdot 1-95 \cdot 7 \%$ to the type strains of the two Thalassomonas species. Sequence similarities to the other species included in the phylogenetic analysis were below $90 \cdot 0 \%$ (Fig. 1).

Phylogenetic analyses based on the neighbour-joining, maximum-likelihood and maximum-parsimony algorithms revealed that strain SMK- $10^{\mathrm{T}}$ and Colwellia species form a clade that is independent of the genus Thalassomonas (Fig. 1). In the neighbour-joining phylogenetic tree, the relationship between this clade and the cluster comprising the two Thalassomonas species was supported by a bootstrap confidence value of $100 \%$ (Fig. 1). Phylogenetic discrimination, supported by high bootstrap resampling values, between the genera Colwellia and Thalassomonas was also shown in previous studies (Yi et al., 2004; Ivanova et al., 2004). These results suggest two possibilities for the classification of strain SMK-10 ${ }^{\mathrm{T}}$ : that it is a member of the genus Colwellia or a member of a new genus. There were no distinct phenotypic, particularly chemotaxonomic, properties to differentiate strain SMK- $10^{\mathrm{T}}$ from the genus Colwellia (Bowman et al., 1998; Yumoto et al., 1998; Nogi et al., 2004). The predominant respiratory lipoquinone (Q-8) of strain SMK- $10^{\mathrm{T}}$ was the same as that of the genus Colwellia (Yumoto et al., 1998; Nogi et al., 2004). The fatty acid profile of strain SMK-10 ${ }^{\mathrm{T}}$ was similar to those of Colwellia species, although there were differences in the proportion of each fatty acid, possibly as a result of the different analytical conditions used, e.g. cultivation and apparatus for the analysis. In particular, two fatty acids, $\mathrm{C}_{16: 1} \omega 7 c$ and iso$\mathrm{C}_{15: 0}$ 2-OH, could not be separated by GLC with the MIDI system in the present study. When the type strains of two Colwellia species, C. maris CIP $106458^{\mathrm{T}}$ and C. hornerae CIP $105821^{\mathrm{T}}$, were analysed in this study, their fatty acid profiles were similar to that of strain SMK-10 $0^{\mathrm{T}}$. Based on our combined phylogenetic and chemotaxonomic analyses, it seems appropriate that strain SMK- $10^{\mathrm{T}}$ be considered as a member of the genus Colwellia. Strain SMK- $10^{\mathrm{T}}$ was distinguishable from recognized Colwellia species by several phenotypic characteristics (Table 1). Despite the fact that we did not undertake any DNA-DNA hybridization experiments, the phylogenetic distinctiveness of strain SMK- $10^{\mathrm{T}}$ is sufficient to separate it from other recognized Colwellia species (Stackebrandt \& Goebel, 1994). Therefore, on the basis of the data presented, strain SMK- $10^{\mathrm{T}}$ should be placed in the genus Colwellia as a member of a novel species, for which the name Colwellia aestuarii sp. nov. is proposed. 
Table 1. Differential phenotypic characteristics of Colwellia aestuarii sp. nov. and other Colwellia species

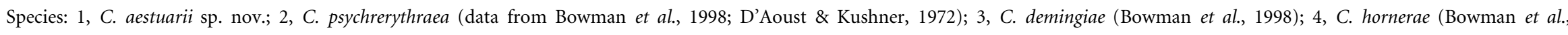

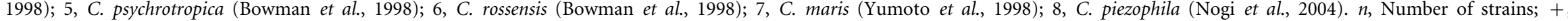

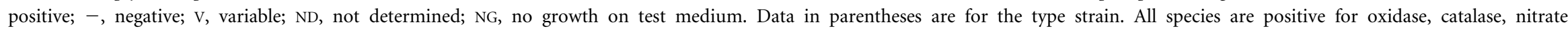

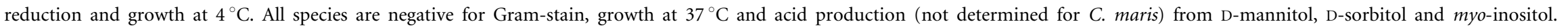

\begin{tabular}{|c|c|c|c|c|c|c|c|c|}
\hline Characteristic & $1(n=1)$ & $2(n=4)$ & $3(n=2)$ & $4(n=1)$ & $5(n=1)$ & $6(n=1)$ & $7(n=1)$ & $8(n=2)$ \\
\hline Cell shape & Curved rod & Rod & Curved rod & Curved rod & Curved rod & Curved rod & Curved rod & Rod \\
\hline Cell size $(\mu \mathrm{m})$ & $0 \cdot 4-0 \cdot 5 \times 1 \cdot 8-3 \cdot 1$ & $0 \cdot 5 \times 2 \cdot 5-3 \cdot 5$ & $0 \cdot 4-0.6 \times 1 \cdot 5-4.5$ & $0 \cdot 4-0 \cdot 8 \times 1 \cdot 5-3 \cdot 0$ & $0 \cdot 4-0 \cdot 8 \times 1 \cdot 5-3 \cdot 0$ & $0 \cdot 4-0 \cdot 8 \times 1 \cdot 5-3 \cdot 0$ & $0 \cdot 6-1 \cdot 0 \times 2 \cdot 0-4 \cdot 0$ & $0 \cdot 8-1 \cdot 0 \times 2 \cdot 0-4 \cdot 0$ \\
\hline Motility & + & + & + & + & + & - & + & + \\
\hline Growth at $25^{\circ} \mathrm{C}$ & + & - & - & - & + & - & - & - \\
\hline Urea & - & $\mathrm{v}(+)$ & - & - & + & + & ND & ND \\
\hline \multicolumn{9}{|l|}{ Hydrolysis of: } \\
\hline Aesculin & - & + & + & + & - & NG & ND & ND \\
\hline Casein & + & + & + & + & + & - & - & - \\
\hline Gelatin & - & $\mathrm{v}(+)$ & - & - & - & - & + & + \\
\hline Starch & - & + & + & + & - & + & - & - \\
\hline Tween 80 & + & + & - & + & + & NG & + & $\mathrm{ND}$ \\
\hline \multicolumn{9}{|l|}{ Utilization of: } \\
\hline L-Arabinose & + & - & - & - & - & + & - & - \\
\hline D-Fructose & - & - & - & - & - & + & - & - \\
\hline D-Galactose & + & - & - & - & - & - & ND & - \\
\hline D-Glucose & + & $\mathrm{v}(+)$ & - & - & - & + & + & ND \\
\hline Maltose & + & - & - & - & - & - & - & ND \\
\hline D-Cellobiose & + & - & - & - & - & - & ND & - \\
\hline D-Trehalose & + & - & - & - & - & - & ND & - \\
\hline Acetate & - & + & + & + & + & + & ND & $\mathrm{ND}$ \\
\hline Citrate & - & - & + & + & - & + & $\mathrm{ND}$ & $\mathrm{ND}$ \\
\hline L-Malate & + & - & - & - & + & + & $\mathrm{ND}$ & $\mathrm{ND}$ \\
\hline \multicolumn{9}{|l|}{ Acid production from: } \\
\hline $\begin{array}{c}\text { D-Mannose, D-fructose, } \\
\text { L-arabinose, sucrose }\end{array}$ & + & - & - & - & - & - & - & - \\
\hline D-Trehalose, lactose & + & - & - & - & - & - & $\mathrm{ND}$ & - \\
\hline Melibiose & + & - & - & - & - & - & - & ND \\
\hline DNA G $+\mathrm{C}$ content $(\mathrm{mol} \%)$ & $39 \cdot 3$ & $35-38$ & 37 & 39 & 42 & 38 & $39 \cdot 4$ & $38 \cdot 5-39 \cdot 1$ \\
\hline
\end{tabular}


Table 2. Cellular fatty acid composition of Colwellia aestuarii SMK-10 ${ }^{\top}$ and some Colwellia species

Taxa: 1, C. aestuarii SMK-10 ${ }^{\mathrm{T}}$ (data from this study); 2, C. maris CIP $106458^{\mathrm{T}}$ (this study); 3, C. maris JCM 10085 ${ }^{\mathrm{T}}$ (Nogi et al., 2004); 4, C. hornerae CIP $105821^{\mathrm{T}}$ (this study); 5, C. hornerae ACAM 607 ${ }^{\mathrm{T}}$ (Bowman et al., 1998); 6, C. psychrerythraea (Bowman et al., 1998); 7, C. demingiae (Bowman et al., 1998); 8, C. psychrotropica ACAM 179 (Bowman et al., 1998); 9, C. rossensis ACAM 608 ${ }^{\mathrm{T}}$ (Bowman et al., 1998); 10, C. piezophila $\mathrm{Y}_{22} 2 \mathrm{G}^{\mathrm{T}}$ and Y251E (Nogi et al., 2004). Values are percentages of total fatty acids. -, Not detected or not described. tr, Trace fatty acid component making up $0.1 \%$ or less of total fatty acid content; fatty acids that represented $<1.0 \%$ in all strains are not indicated.

\begin{tabular}{|c|c|c|c|c|c|c|c|c|c|c|}
\hline Fatty acid & 1 & 2 & 3 & 4 & 5 & 6 & 7 & 8 & 9 & 10 \\
\hline \multicolumn{11}{|l|}{ Straight-chain } \\
\hline $\mathrm{C}_{10: 0}$ & $1 \cdot 7$ & $2 \cdot 0$ & - & $0 \cdot 9$ & - & - & - & - & - & - \\
\hline $\mathrm{C}_{11: 0}$ & - & $1 \cdot 6$ & - & $0 \cdot 2$ & - & - & - & - & - & - \\
\hline $\mathrm{C}_{12: 0}$ & $0 \cdot 5$ & $1 \cdot 9$ & 2 & - & - & - & - & - & - & $1-2$ \\
\hline $\mathrm{C}_{14: 0}$ & $2 \cdot 3$ & $1 \cdot 0$ & - & $0 \cdot 9$ & $3 \cdot 0$ & $5 \cdot 1-7 \cdot 8$ & $7 \cdot 6-8 \cdot 0$ & $0 \cdot 8$ & $4 \cdot 6$ & 9 \\
\hline $\mathrm{C}_{15: 0}$ & $4 \cdot 8$ & $8 \cdot 0$ & 4 & $5 \cdot 3$ & $2 \cdot 9$ & $1 \cdot 7-11 \cdot 0$ & $0 \cdot 9-1 \cdot 4$ & $2 \cdot 7$ & $2 \cdot 9$ & 3 \\
\hline $\mathrm{C}_{16: 0}$ & $9 \cdot 9$ & $15 \cdot 0$ & 25 & $7 \cdot 7$ & $13 \cdot 5$ & $26 \cdot 8-33 \cdot 2$ & $21 \cdot 9-23 \cdot 6$ & $21 \cdot 9$ & $27 \cdot 1$ & $31-33$ \\
\hline $\mathrm{C}_{17: 0}$ & $2 \cdot 5$ & $2 \cdot 6$ & 3 & $1 \cdot 0$ & - & $0-1 \cdot 3$ & $\operatorname{tr}$ & $1 \cdot 5$ & $0 \cdot 1$ & - \\
\hline $\mathrm{C}_{18: 0}$ & - & - & - & - & $2 \cdot 0$ & $0 \cdot 1-2 \cdot 4$ & $0 \cdot 2-0 \cdot 5$ & $0 \cdot 4$ & $\operatorname{tr}$ & - \\
\hline \multicolumn{11}{|l|}{ Branched } \\
\hline iso- $\mathrm{C}_{16: 0}$ & $10 \cdot 4$ & - & - & $15 \cdot 4$ & $10 \cdot 3$ & $0-0 \cdot 2$ & - & - & - & - \\
\hline \multicolumn{11}{|l|}{ Unsaturated } \\
\hline $\mathrm{C}_{14: 1^{*}}$ & - & - & 2 & - & $2 \cdot 8$ & $5 \cdot 1-7 \cdot 3$ & $9 \cdot 1-9 \cdot 3$ & $2 \cdot 0$ & $2 \cdot 8$ & 2 \\
\hline $\mathrm{C}_{15: 1}$ & $10 \cdot 9$ & $13 \cdot 4$ & 6 & $23 \cdot 7$ & $21 \cdot 4$ & $0-2 \cdot 7$ & $1 \cdot 9-2 \cdot 6$ & $4 \cdot 3$ & $4 \cdot 1$ & 3 \\
\hline $\mathrm{C}_{16: 1} \dagger$ & - & - & 51 & - & $15 \cdot 4$ & $31 \cdot 4-36 \cdot 3$ & $37 \cdot 5-37 \cdot 8$ & $56 \cdot 8$ & $43 \cdot 4$ & $48-50$ \\
\hline $\mathrm{C}_{16: 1} \omega 7 c$ and/or iso- $\mathrm{C}_{15: 0} 2-\mathrm{OH} \ddagger$ & $23 \cdot 6$ & $32 \cdot 8$ & - & $24 \cdot 0$ & - & - & - & - & - & - \\
\hline $\mathrm{C}_{16: 1} \omega 9 c$ & $5 \cdot 6$ & $4 \cdot 2$ & - & $1 \cdot 8$ & $2 \cdot 0$ & $6 \cdot 2-8 \cdot 8$ & $9 \cdot 5-11 \cdot 8$ & - & $1 \cdot 8$ & - \\
\hline $\mathrm{C}_{17: 1}$ & $11 \cdot 8$ & $6 \cdot 2$ & 4 & $6 \cdot 2$ & $7 \cdot 5$ & $0-2 \cdot 2$ & $\operatorname{tr}$ & $5 \cdot 4$ & $0 \cdot 5$ & - \\
\hline $\mathrm{C}_{18: 1} \omega 9 c$ & $0 \cdot 6$ & - & - & - & $1 \cdot 4$ & $0-1 \cdot 7$ & $\operatorname{tr}-0 \cdot 2$ & $0 \cdot 3$ & $0 \cdot 8$ & - \\
\hline $\mathrm{C}_{18: 1} \omega 7 c$ & $1 \cdot 2$ & $0 \cdot 7$ & - & $0 \cdot 8$ & - & $0 \cdot 3-2 \cdot 1$ & $1 \cdot 3-1 \cdot 4$ & $1 \cdot 9$ & $4 \cdot 2$ & - \\
\hline $\mathrm{C}_{20: 5} \omega 3 c$ & - & - & - & - & - & $0-1 \cdot 5$ & - & $0 \cdot 1$ & $\operatorname{tr} \dagger$ & - \\
\hline $\mathrm{C}_{22: 6} \omega 3 c$ & - & - & - & - & $2 \cdot 1$ & $5 \cdot 5-8 \cdot 0$ & $1 \cdot 7-2 \cdot 2$ & $0 \cdot 7$ & $6 \cdot 0$ & - \\
\hline \multicolumn{11}{|l|}{ Hydroxy } \\
\hline $\mathrm{C}_{11: 0} 3-\mathrm{OH}$ & $2 \cdot 6$ & $1 \cdot 9$ & - & $1 \cdot 9$ & - & - & - & - & - & - \\
\hline $\mathrm{C}_{12: 0} 3-\mathrm{OH}$ & $2 \cdot 5$ & $3 \cdot 0$ & 3 & $0 \cdot 8$ & - & - & - & - & - & $0-1$ \\
\hline $\mathrm{C}_{16: 0} 3-\mathrm{OH}$ & - & $1 \cdot 1$ & - & - & - & - & - & - & - & - \\
\hline iso- $\mathrm{C}_{12: 0} 3-\mathrm{OH}$ & $5 \cdot 3$ & - & - & $2 \cdot 7$ & - & - & - & - & - & - \\
\hline
\end{tabular}

${ }^{*}$ Indicated as $C_{14: 1} \omega 7 c$ by Bowman et al. (1998).

$\dagger$ Indicated as $C_{16: 1} \omega 7 c$ by Bowman et al. (1998).

¥Could not be separated by GLC with the MIDI system.

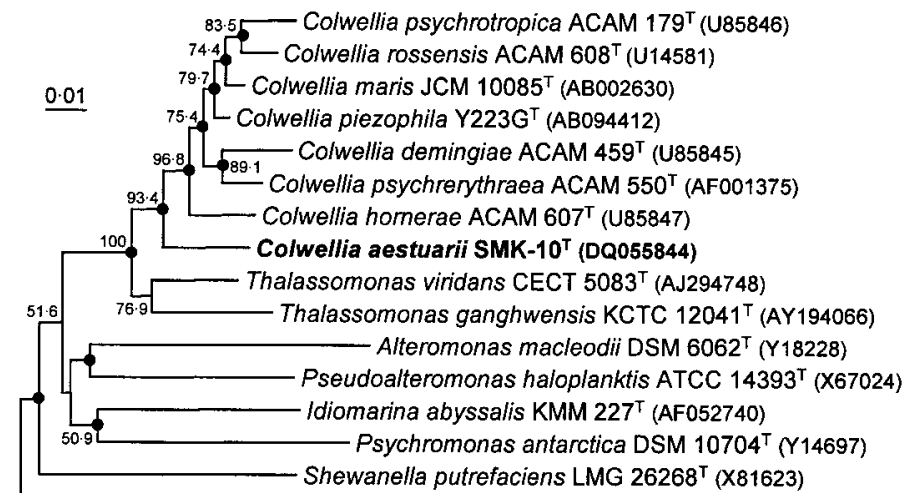

Pseudomonas aeruginosa DSM $50071^{\top}$ (X06684)
Fig. 1. Neighbour-joining tree showing the phylogenetic positions of strain SMK-10 and other related taxa based on 16S rRNA gene sequences. Only bootstrap values (expressed as percentages of 1000 replications) of $>50 \%$ are shown at the branch points. Dots indicate that the corresponding nodes are also recovered in trees generated with the maximum-likelihood and maximumparsimony algorithms. Bar, 0.01 substitutions per nucleotide position. 


\section{Description of Colwellia aestuarii sp. nov.}

Colwellia aestuarii (aes.tu.a'ri.i. L. gen. $n$. aestuarii of a tidal flat, from where the type strain was isolated).

Cells are Gram-negative, curved rods, $0 \cdot 4-0 \cdot 5 \times 1 \cdot 8-3 \cdot 1 \mu \mathrm{m}$. Motile by means of a single polar flagellum. Growth occurs under anaerobic conditions on MA and on MA supplemented with nitrate. Growth occurs at 4 and $32{ }^{\circ} \mathrm{C}$ with an optimum temperature range of $25-30{ }^{\circ} \mathrm{C}$. Optimal $\mathrm{pH}$ range for growth is $7 \cdot 0-8 \cdot 0$; growth occurs weakly at $\mathrm{pH} 5 \cdot 0$ but not at $4 \cdot 5$. Optimal growth occurs in the presence of $2-3 \%$ $(\mathrm{w} / \mathrm{v}) \mathrm{NaCl}$; growth occurs in the presence of $6 \%(\mathrm{w} / \mathrm{v})$ $\mathrm{NaCl}$ but not in the presence of $>7 \% \mathrm{NaCl}$. Tweens 20,40 and 60 are hydrolysed, but hypoxanthine, xanthine and Ltyrosine are not. In assays with the API ZYM system, alkaline phosphatase, esterase (C4), esterase lipase (C8), leucine arylamidase, acid phosphatase, naphthol-AS-BI phosphohydrolase and $\beta$-glucosidase are present, but lipase (C14), valine arylamidase, cystine arylamidase, trypsin, $\alpha$-chymotrypsin, $\alpha$ galactosidase, $\beta$-galactosidase, $\beta$-glucuronidase, $\alpha$-glucosidase, $N$-acetyl- $\beta$-glucosaminidase, $\alpha$-mannosidase and $\alpha$-fucosidase are absent. D-Xylose and salicin are utilized as sole carbon and energy sources. Benzoate, formate, L-glutamate, D-mannose, pyruvate, succinate and sucrose are not utilized. Acid is produced from D-cellobiose, D-galactose, D-glucose, D-ribose, L-rhamnose, D-xylose and maltose. Acid is not produced from D-melezitose or D-raffinose. Susceptible to carbenicillin, cephalothin, chloramphenicol, gentamicin, kanamycin, neomycin, novobiocin, oleandomycin, penicillin G, polymyxin B and streptomycin, but not to ampicillin, lincomycin or tetracycline. The major cellular fatty acids are $\mathrm{C}_{16: 1} \omega 7 c$ and/or iso- $\mathrm{C}_{15: 0} 2-\mathrm{OH}, \mathrm{C}_{17: 1}, \mathrm{C}_{15: 1}$ and iso$\mathrm{C}_{16: 0}$. The predominant ubiquinone is $\mathrm{Q}-8$. The DNA $\mathrm{G}+\mathrm{C}$ content is $39 \cdot 3 \mathrm{~mol} \%$.

The type strain, SMK $-10^{\mathrm{T}}\left(=\mathrm{KCTC} 12480^{\mathrm{T}}=\mathrm{DSM} 17314^{\mathrm{T}}\right)$, was isolated from a tidal flat sediment from Saemankum, Korea.

\section{Acknowledgements}

This work was supported by the 21C Frontier Program of Microbial Genomics and Applications (grant MG05-0401-2-0) and an NRL research programme from the Ministry of Science and Technology (MOST) of the Republic of Korea.

\section{References}

Baumann, P. \& Baumann, L. (1981). The marine Gram-negative eubacteria: genera Photobacterium, Beneckea, Alteromonas, Pseudomonas, and Alcaligenes. In The Prokaryotes, pp. 1302-1331. Edited by M. P. Starr, H. Stolp, H. G. Trüper, A. Balows \& H. G. Schlegel. Berlin: Springer.

Bowman, J. P., Gosink, J. J., McCammon, S. A., Lewis, T. E., Nichols, D. S., Nichols, P. D., Skerratt, J. H., Staley, J. T. \& McMeekin, T. A. (1998). Colwellia demingiae sp. nov., Colwellia hornerae sp. nov., Colwellia rossensis sp. nov. and Colwellia psychrotropica sp. nov.: psychrophilic Antarctic species with the ability to synthesize doco-

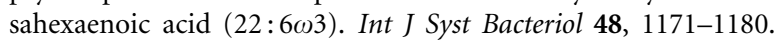

Bruns, A., Rohde, M. \& Berthe-Corti, L. (2001). Muricauda ruestringensis gen. nov., sp. nov., a facultatively anaerobic, appendaged bacterium from German North Sea intertidal sediment. Int J Syst Evol Microbiol 51, 1997-2006.

Cohen-Bazire, G., Sistrom, W. R. \& Stanier, R. Y. (1957). Kinetic studies of pigment synthesis by non-sulfur purple bacteria. J Cell Comp Physiol 49, 25-68.

Cowan, S. T. \& Steel, K. J. (1965). Manual for the Identification of Medical Bacteria. London: Cambridge University Press.

D’Aoust, J. Y. \& Kushner, D. J. (1972). Vibrio psychroerythrus sp. n.: classification of the psychrophilic marine bacterium, NRC 1004. J Bacteriol 111, 340-342.

Deming, J. W., Somers, L. K., Straube, W. L., Swartz, D. G. \& MacDonell, M. T. (1988). Isolation of an obligately barophilic bacterium and description of a new genus, Colwellia gen. nov. Syst Appl Microbiol 10, 152-160.

Ivanova, E. P., Flavier, S. \& Christen, R. (2004). Phylogenetic relationships among marine Alteromonas-like proteobacteria: emended description of the family Alteromonadaceae and proposal of Pseudoalteromonadaceae fam. nov., Colwelliaceae fam. nov., Shewanellaceae fam. nov., Moritellaceae fam. nov., Ferrimonadaceae fam. nov., Idiomarinaceae fam. nov. and Psychromonadaceae fam. nov. Int J Syst Evol Microbiol 54, 1773-1788.

Komagata, K. \& Suzuki, K. (1987). Lipids and cell-wall analysis in bacterial systematics. Methods Microbiol 19, 161-203.

Lanyi, B. (1987). Classical and rapid identification methods for medically important bacteria. Methods Microbiol 19, 1-67.

Leifson, E. (1963). Determination of carbohydrate metabolism of marine bacteria. J Bacteriol 85, 1183-1184.

Macián, M. C., Ludwig, W., Schleifer, K. H., Garay, E. \& Pujalte, M. J. (2001). Thalassomonas viridans gen. nov., sp. nov., a novel marine $\gamma$ proteobacterium. Int J Syst Evol Microbiol 51, 1283-1289.

Nogi, Y., Hosoya, S., Kato, C. \& Horikoshi, K. (2004). Colwellia piezophila sp. nov., a novel piezophilic species from deep-sea sediments of the Japan Trench. Int J Syst Evol Microbiol 54, 1627-1631.

Sasser, M. (1990). Identification of Bacteria by Gas Chromatography of Cellular Fatty Acids. Newark, DE: MIDI Inc.

Stackebrandt, E. \& Goebel, B. M. (1994). Taxonomic note: a place for DNA-DNA reassociation and $16 \mathrm{~S}$ rRNA sequence analysis in the present species definition in bacteriology. Int J Syst Bacteriol 44, 846-849.

Staley, J. T. (1968). Prosthecomicrobium and Ancalomicrobium: new prosthecate freshwater bacteria. J Bacteriol 95, 1921-1942.

Tamaoka, J. \& Komagata, K. (1984). Determination of DNA base composition by reversed phase high performance liquid chromatography. FEMS Microbiol Lett 25, 125-128.

Yi, H., Bae, K. S. \& Chun, J. (2004). Thalassomonas ganghwensis sp. nov., isolated from tidal flat sediment. Int J Syst Evol Microbiol 54, 377-380.

Yoon, J.-H., Kim, H., Kim, S.-B., Kim, H.-J., Kim, W. Y., Lee, S. T., Goodfellow, M. \& Park, Y.-H. (1996). Identification of Saccharomonospora strains by the use of genomic DNA fragments and rRNA gene probes. Int $J$ Syst Bacteriol 46, 502-505.

Yoon, J.-H., Lee, S. T. \& Park, Y.-H. (1998). Inter- and intraspecific phylogenetic analysis of the genus Nocardioides and related taxa based on 16S rDNA sequences. Int J Syst Bacteriol 48, 187-194.

Yoon, J.-H., Kang, K. H. \& Park, Y.-H. (2003). Psychrobacter jeotgali sp. nov., isolated from jeotgal, a traditional Korean fermented seafood. Int J Syst Evol Microbiol 53, 449-454.

Yumoto, I., Kawasaki, K., Iwata, H., Matsuyama, H. \& Okuyama, H. (1998). Assignment of Vibrio sp. strain ABE-1 to Colwellia maris sp. nov., a new psychrophilic bacterium. Int J Syst Bacteriol 48, 1357-1362. 